\title{
ERRATA
}

\section{Only Part of the Protoxin Gene of Bacillus thuringiensis subsp. berliner 1715 Is Necessary for Insecticidal Activity}

\author{
HIROETSU WABIKO, GARY A. HELD, AND LEE A. BULLA, JR.
}

Department of Biochemistry, College of Agriculture, University of Wyoming, Laramie, Wyoming 8207I

Volume 49, no. 3, p. 708: The Acknowledgments section should read: "This research was supported, in part, by grants from Stauffer Chemical Co., Richmond, Calif., and the Agency for International Development, U.S. Department of State, Washington, D.C."

\section{Degradation of Halogenated Aliphatic Compounds by Xanthobacter autotrophicus GJ10}

DICK B. JANSSEN, ALEX SCHEPER, LUBBERT DIJKHUIZEN, AND BERNARD WITHOLT

Department of Biochemistry, Groningen Biotechnology Center, University of Groningen, Nijenborgh 16, 9747 AG Groningen, and Department of Microbiology, Groningen Biotechnology Center, University of Groningen, Kerklaan 30, 975I NN Haren, The Netherlands

Volume 49, no. 3, p. 674, column 2, line 26: "Xantobacter" should read "Xanthobacter."

Page 676, column 2, lines 37-38: "Oxidation of 2-chloroethanol has also been found in 2-chloroethanol with pseudomonads" should read "Oxidation of 2-chloroethanol has also been found with 2-chloroethanol-utilizing pseudomonads."

Page 677, Literature Cited: In reference 6, "S. Staub" should read "D. Staub"; the title of reference 12 should read "Identification and analysis of organic pollutants in water"; in reference 20, "Rittman, B. E." should read "Rittmann, B. E." 